\title{
Learning Case Study in the Pandemic Covid-19: Learning Targets, Needs Analysis, Obstacles, and Solutions
}

\author{
Muh. Makhrus ${ }^{1, *}$, Ahmad Abtokhi $^{2}$, Zul Hidayatullah $^{3}$
}

\author{
${ }^{1}$ Physic Education, Faculty of Teacher Training and Education, Universitas Mataram, Indonesia \\ ${ }^{2}$ Physics, Universitas Islam Negeri Maulana Malik Ibrahim Malang, Indonesia \\ ${ }^{3}$ Master Program Physics Education, Faculty of Mathematics and Natural Sciences, Universitas Negeri \\ Yogyakarta, Indonesia \\ *Corresponding author.Email: makhrus.fkip@unram.ac.id,
}

\begin{abstract}
COVID-19 pandemic has changed the learning system in Indonesia. Learning that is usually carried out face-to-face must be changed to online learning. The fact is online learning is not running as expected. This research aims to describe learning during the COVID-19 pandemic by examining elements of learning targets, analyzing needs, obstacles, and solutions. This type of research is a case study using literature studies in the form of articles and field studies to see the learning process during the pandemic. The subjects in this study were principals, physics teachers, and students spread across four schools in Mataram, West Nusa Tenggara. Data collection was carried out by interview and observation. The results showed that the learning target does not have to match the target achievement of the 2013 curriculum. Learning focuses more on providing experiences to students. During the pandemic, learning obstacles are 1) limited mastery of technology, 2) limited internet access and wasteful data packages, and 3) less interaction. The solution given by several schools is by using video lessons and face-to-face learning using small groups.
\end{abstract}

Keywords: Learning, Pandemic COVID-19

\section{INTRODUCTION}

COVID-19 is a virus case that emerged in Wuhan, China. This virus is capable of infecting humans and has a hazardous impact. This virus's characteristic is that it can spread rapidly from object to human and from human to human. As a result of this virus, almost all aspects of life are disturbed and hampered. The education sector also experienced significant disruptions. Almost all countries affected by the COVID-19 pandemic have implemented policies by closing schools to colleges. This is done to reduce the level of activity and contact that occurs during the learning process. This policy is called Physical Distancing. This problem requires educational institutions and educators to apply appropriate learning [1].

The Indonesian government implements a social distancing policy to prevent offline learning (face-toface) in schools. It was done to prevent the spread of COVID-19. Finally, learning is transformed into an online system with various learning platforms/media. The regulation issued by the government is online learning to implement physical distancing.

This online learning is an alternative learning solution during a pandemic. The implementation of a guarding distance policy certainly requires a learning process from home. Learning, which is usually done face-to-face, then changes suddenly, of course, creates new challenges for educational institutions, educators, students, and parents. This paradigm certainly has a significant impact on the learning process, especially at the primary and secondary school levels. This is because all parties have to start and get used to the use of technology as a means so that the teaching and learning process can continue as usual. The learning paradigm is essential for current conditions to achieve the goals of national education. Implementing learning that changes drastically and suddenly without being planned will certainly experience various obstacles from the school, teachers, students, and parents. Therefore, the government is continuously improving education construction through the curriculum, followed by schools improving themselves to provide maximum 
educational services. Teachers are required to prepare learning media and strategies that can accommodate students' backgrounds for taking distance learning, both online and offline.

Online learning (E-Learning) is a learning system that utilizes information and communication technology facilities using online media such as WhatsApp, Zoom, YouTube, Google Classroom, and continuing the learning process even without face-to-face meetings at school [2]. Students and teachers are also not always physically present at school. To do so, it requires hardware and software to access information and carry out learning anywhere [3].

This online learning is expected can help students learn during this pandemic to achieve learning targets. The fact is online learning is not running effectively as expected. Online learning that has occurred so far has only been limited to providing materials and assignments without continuous interaction between teachers and students so that learning becomes monotonous and unattractive [4]. Another problem that arises is that many students are not used to using Elearning. With the pandemic COVID-19, students must be able to learn using E-learning. This causes students who are not used to having to adapt first [5].

The use of various platforms currently available is tailored to the learning process's needs to be carried out. If the desired learner wants a presentation of information in the form of a presentation, you can use the Zoom Cloud Meeting application and Google Meet. The success or failure of the learning process from home is very dependent on all parties, meaning that parents are currently also participating in supervising and guiding their children in participating in distance learning provided by the school. This study aims to describe the learning that occurred during this pandemic by analyzing learning targets, needs, obstacles, and learning solutions. The results of this research can be used as material for consideration of future learning.

\section{RESEARCH METHOD}

The type of this research is a case study research with a qualitative descriptive approach. The qualitative descriptive approach produces data, not numbers but descriptive data from interviews, observations, field notes, and other official records [6]. The research was conducted by reviewing articles about learning during the pandemic that has been published in national and international journals and describing the learning process activities during the Covid-19 pandemic. This research was conducted in 4 (four) schools randomly selected in Mataram, West Nusa Tenggara. This study's subjects are of school principals, teachers, and students in senior high schools (SMA/MA/SMK). The schools referred to are two senior high schools under the ministry of education and culture and two senior high schools under religion's ministry. The data collection process in this study used an interview guideline sheet and an observation sheet for teacher-student learning activities.

\section{RESULT AND DISCUSSION}

The period of the COVID-19 pandemic requires learning in schools to be carried out online. This is done to get lessons even though the COVID-19 pandemic constrains them. The following is an analysis of the needs, obstacles, and solutions carried out by several schools to carry out learning during the COVID-19 pandemic based on the results of literature reviews and field studies in several schools in Lombok, West Nusa Tenggara.

\subsection{Result}

It is found that online learning has not been effective due to limited supporting facilities and infrastructure. Judging from its implementation during the last few months of the even semester of the $2019 / 2020$ academic year related to the application of a distance learning system (online), it turns out that there are still many deficiencies found both from the preparation stage to the evaluation stage of learning achievement. The difficulty was felt by the board of educators and students in one of the schools under the ministry of religion. During the online learning system application, the teachers find it difficult to measure the abilities possessed by students, especially in the aspects of attitudes and psychomotor.

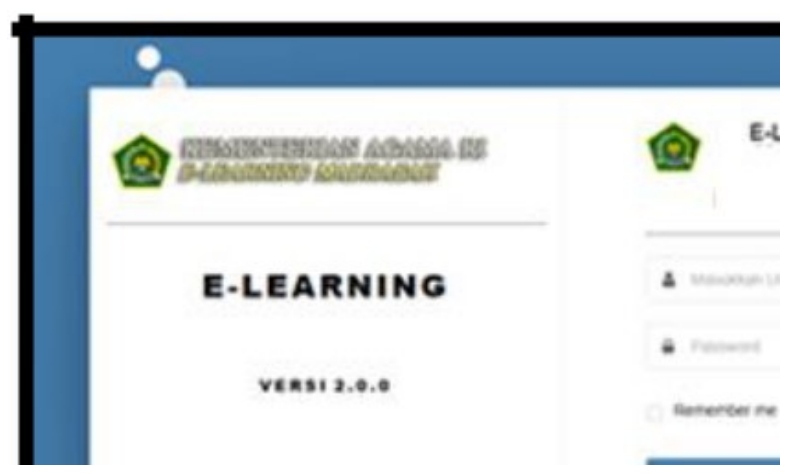

Figure 1. E-Learning system in a school under the Ministry of Religion

Online learning carried out in schools using the Ministry of Religion's E-Learning platform. The application of a distance learning system with this platform requires that teaching materials and student assignments be uploaded through the system, making educators feel unsure about students' results. This uncertainty was because this E-learning application (Figure 1) only provided visual-based features in the 
previous semester, meaning that educators could not directly monitor students in carrying out the learning process. Hence, the Graduate Competency Standard (SKL) will be difficult to achieve in the learning process during the COVID-19 pandemic. Educators are highly expected to use extra strategies to find solutions to measure the three existing competencies (cognitive, affective, and psychomotor). Implementing the 2013 curriculum has not been completely carried out perfectly because the learning process during this pandemic only focuses on the realm of knowledge. The two other aspects should also be assessed in the learning process because each student has a different character so that when an educator can master the three aspects of the assessment, the educator can measure the extent to which the student's level of the successful learning process as a whole. Another obstacle to consider in learning during a pandemic is the breadth of learning materials, especially physics.

Through the evaluation process at the end of the semester, it was determined that there needed to be modifications or improvements related to implementing the distance learning process at the school, following recommendations from the government to identify related materials considered important to be studied students. This illustrates that the government gives freedom to educators in compiling subject matter. This policy makes it easier for educators and students to carry out the learning process compared to the previous semester. Also, educators are emphasized to continue to accompany and facilitate students during the learning process by providing information and motivation that can increase students' interest in staying enthusiastic about learning during this pandemic.

Slightly different, the other schools under the ministry of religion have implemented an online learning system and face-to-face learning with small groups. The school uses the WhatsApp Group platform (Figure 2) to carry out online learning. This is because the Whatsapp group is considered the easiest facility to reach by all students and teachers. WhatsApp is easy to reach by teachers and students in online learning, but the discussion should be strictly under the topic [19]. While some teachers complained about the lack of interaction on WhatsApp, the students complained about the high intensity of giving assignments, so that students felt overwhelmed [20].

Apart from using the WhatsApp group (WAG) as the most accessible alternative for all students and educators, the learning management system (Google Classroom) application is also an additional application in the learning process. It can support the education system during the current pandemic as they consider it interesting and motivate the students to get involved in the learning process.

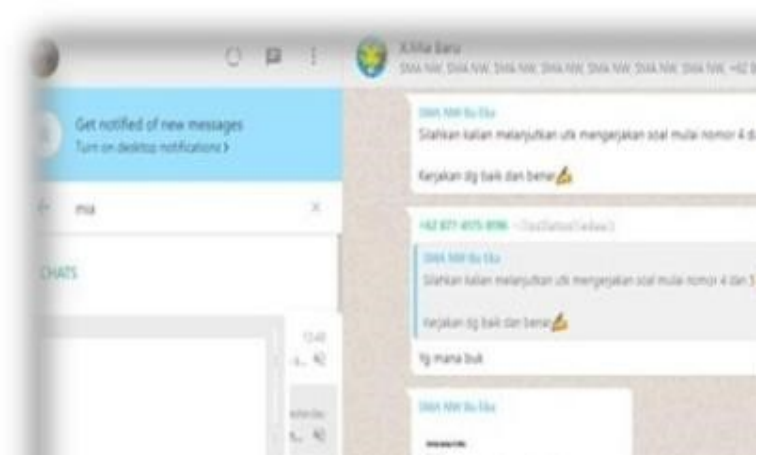

Figure 2. Learning using the Whatsapp Group (WAG)

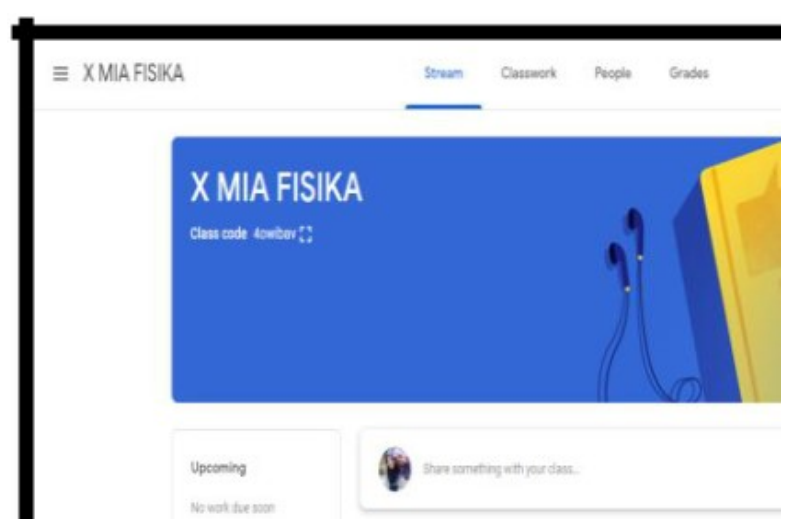

Figure 3 Learning Using Google Classroom

The learning media system is not an obstacle to learning with an online system, but the availability of a quota that requires a high cost for students and educators to facilitate learning needs. The quota purchased for the internet has increased, and many parents are not ready to increase their budget in providing internet networks. This becomes one of the obstacles in the online learning process. Hence, the Graduates Competency Standards (SKL) will be difficult to achieve in the learning process during the COVID-19 pandemic. It might be caused by the materials that should be adjusted. The government gives schools the freedom to implement a learning system related to the material and its activities. This policy certainly helps the educators and students in carrying out the learning process. The education system policy, especially in schools, is to start implementing offline learning following health protocols and not creating an association.

Offline learning is treated for students in the dormitory or Mataram area that does not have facilities for online learning. The procedures are carried out according to the health protocol, such as washing hands with soap and running water, using a hand sanitizer, wearing a mask, social distancing, or physical distancing. Besides, since the learning process is 
conducted gradually, the schedule is flexible, and students' numbers are limited. Fortunately, it might give the students some positive impacts.

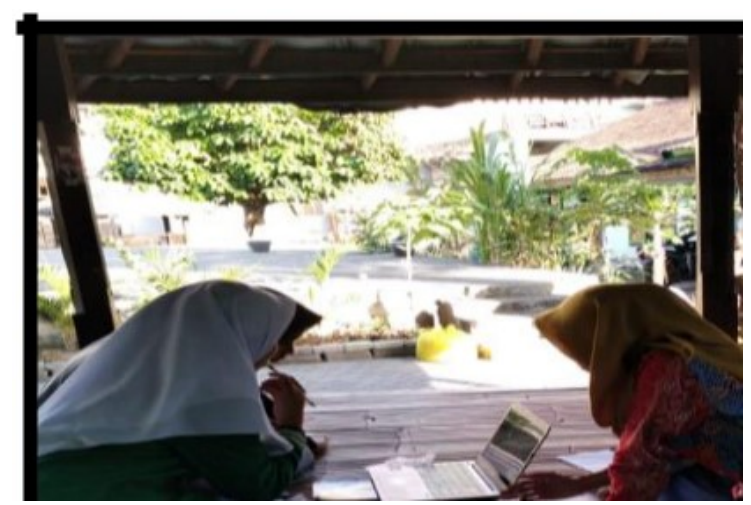

Figure 4 Offline learning with small groups

Not much different from the two schools under the Ministry of Religion Affairs, the results of interviews and observations in two schools under the Ministry of Education and Culture said that there were no specific learning targets during the COVID-19 pandemic. Also, there is no demand to complete the 2013 curriculum and learning using curriculum simplification under special conditions prepared by the ministry of education and culture. Schools are also allowed to simplify the curriculum independently. Learning objectives are also not too burdened to meet targets in the curriculum. The learning system is implemented in online learning. Teachers can learn together at the same time using groups on social media such as WhatsApp (WA), Telegram, Instagram, Zoom, or other media as learning media. Thus, the teacher can ensure students take part in learning simultaneously, even in different places.

Moreover, the school stated that online learning that was enforced was given the freedom to teachers and students in its implementation. Two important points become learning targets during the pandemic: providing meaningful independent learning experiences to students and getting contextual learning. Independent learning as the first target is intended to provide students with meaningful learning experiences and not achieve curriculum targets. In terms of the policy, education during the COVID-19 emergency was at odds with the subject matter's imposition according to curriculum targets. The education policy clearly outlines that curriculum targets' achievement is not a reference either in determining class promotion or graduation. Also, student-centered independent learning makes students have meaningful learning experiences. Student-centered learning methods provide space for each student to learn something unique, interesting, and useful for their lives. Teacher supervision strategies also determine the success rate of online learning. In supervising students, facilitators, and motivators for students who must be played by the teacher. It can increase students' understanding and feel meaningful learning during the independent learning process at home. By utilizing various existing digital media communication, the time and opportunities to communicate are more adjustable.

Unexpectedly, the application of distance learning during the COVID-19 pandemic has both many obstacles and positive impacts on Indonesia's education system. This pandemic indirectly encourages all educators to master and utilize various technologies, information, and communication (ICT) in supporting the learning process. It follows one of the competencies that both educators and students must possess in the 21 st century, digital literacy skills. This condition teaches many things, including preparing for all the possibilities in realizing 21 st-century learning. Various efforts have been prepared by several schools in following up on the evaluation results of the distance learning process over the last 3-4 months, including 1) Conducting socialization and workshops for educators; 2) Conducting outreach to parents and students to apply Blended Learning; 3) Prepare supporting facilities and infrastructure such as quotas, wifi in the school area, computers, and consultation on the E-Learning system; 4) Carry out online learning using a variety of platforms that are available and accessible to students; 5) Carry out offline learning with small groups to help students who feel distressed in teaching and learning. Of course, offline learning is carried out while still implementing health protocols according to government recommendations. All efforts and possibilities are implemented, even more, various schools have made several creative breakthroughs according to educators' conditions (teachers) and students.

\subsection{Discussion}

Several factors that might cause online learning's ineffectiveness are limited internet access and poor digital literacy. Another factor is the lack of interaction between teachers and students due to the overload of assignments [6]. The materials and assignments are getting harder to understand as communication between teachers and students are deemed insufficient [6]. Additionally, problems that hinder the effectiveness of online learning are caused by 1) Limited mastery of information technology by teachers and students, 2) Inadequate facilities and infrastructure, and 3) Inadequate budget provision [8]. Even though various platforms or applications such as WhatsApp Group, Google Classroom, Zoom, Google Meet, and several Elearning platforms are provided by each agency, online learning is still not effective enough interest and motivation in learning. Then there are also cases of internet quota draining in Zoom, low understanding of the material in Google Classroom, and slow responding in WhatsApp Group as well [9]. The poor signal quality impacts the number of students who participate in the class, only about $50 \%$ of them [13]. Also, the students are not optimal in learning material distributed by the teacher [14]. The problem with using Google Classroom is that students do not understand the teacher's material, 
especially material in the form of analysis/calculation. The zoom meeting application can facilitate interactive learning but must use good internet access and a large internet quota [15]. Moreover, one of the effects felt by students in the teaching and learning process at home is that students feel forced to learn distance learning without adequate facilities and infrastructure. The next obstacle is that the students are not getting used to distance learning, so it takes time to adapt to the online learning system [10].

Based on several problems and obstacles in online learning, it is necessary to provide a solution to learn to be effective. The use of a platform that matches the characteristics of the subject matter and student characteristics is a necessary consideration in learning. The use of interactive learning media and videos is another alternative that can be used in online learning. Instructional and practicum videos are also an alternative solution for effective online learning [12]. The schools also need to provide training and assistance for teachers who have limitations in making videos and teaching media as videos can be an alternative and a solution to overcome the decline in understanding when the learning material is online [16].

Quiziz as an educational game is also an alternative that could improve students' participation during the learning process [17]. In addition, things that need to be considered are local environmental conditions and online learning facilities used by teachers and students. Every teacher and student from each region has limitations in using online learning platforms [18].

\section{CONCLUSION AND SUGGESTION}

Learning targets of online learning should be focused on providing students with independent learning experiences and should not force students and teachers to conform to the 2013 curriculum targets. Limited ability to use technology, quite a lot of internet quotas and ineffectiveness in assessing all student competencies are examples of obstacles during this pandemic learning period. The use of instructional videos is an alternative solution to make students understand the material. Another alternative is offline learning with small groups by implementing health protocols.

\section{REFERENCES}

[1] Z. Abidin, Rumansyah, and K. Arizona, "Pembelajaran Online Berbasis Proyek Salah Satu Solusi Kegiatan Belajar Mengajar di Tengah Pandemi Covid-19," J. Ilm. Profesi Pendidik., Vol. 5, No. 1, Pp. 64-70, 2020.

[2] R. Pakpahan and Y. Fitriani, "Analisa Pemanfaatan Teknologi Informasi Dalam
Pembelajaran Jarak Jauh Di Tengah Pandemi Virus Corona Covid-19," Jisamar J. Inf. Syst., Appl., Manag., Account. Researh, Vol. 4, No. 2, Pp. 30-36, 2020.

[3] Firman and S. R. Rahman, "Pembelajaran Online di Tengah Pandemi Covid-19," Indones. J. Educ. Sci., Vol. 02, No. 02, Pp. 81-89, 2020.

[4] M. Saeri, "Pembelajaran Fisika Dengan Video Rekam Layar Pada Masa Pandemi Covid -19," Karang. J. Kependidikan, Pembelajaran, dan Pengemb., Vol. 2, No. 2, Pp. 26-32, 2020.

[5] I. Z. Ichsan Et Al., "Covid-19 dan E-Learning: Perubahan Strategi Pembelajaran Sains dan Lingkungan di SMP," J. Inov. Pembelajaran, Vol. 6, No. 1, Pp. 50-61, 2020.

[6] Napsawati, “Analisis Situasi Pembelajaran IPA Fisika Dengan Metode Daring di Tengah Wabah Covid-19," Karst J. Pendidik. Fis. dan Ter., Vol. 3, No. 1, Pp. 6-12, 2020.

[7] A. Sadikin and A. Hamidah, "Pembelajaran Daring di Tengah Wabah Covid-19 (Online Learning in the Middle Of The Covid-19 Pandemic)," Biodik J. Ilm. Pendidik. Biol., Vol. 6, No. 1, Pp. 214-224, 2020.

[8] R. H. S. Aji, "Dampak Covid-19 Pada Pendidikan Di Indonesia: Sekolah, Keterampilan, dan Proses Pembelajaran," Salam J. Sos. Dan Budaya Syar-I, Vol. 7, No. 5, Pp. 395-402, 2020.

[9] M. Hakim and A. Mulyapradana, "Pengaruh Penggunaan Media Daring dan Motivasi Belajar Terhadap Kepuasan Mahasiswa Pada Saat Pandemi Covid-19," Vol. 4, No. 2, Pp.154-160, 2020.

[10] A. Purwanto Et Al., "Studi Eksploratif Dampak PandemiCovid-19 Terhadap Proses Pembelajaran Online di Sekolah," J. Educ. Psychol. Couns., Vol. 2, No. 1, Pp. 1-12, 2020.

[11] Hermansyah, F. Yahya, S. Fitriyanto, Musahrain, And Nurhairunnisah, "Kemandirian Belajar Calon Guru Fisika Melalui Pembelajaran Berbasis Lms: Schoology," Indones. J. Stem Educ., Vol. 2, No. 1, Pp. 34 42, 2020.

[12] A. Permata and Y. B. Bhakti, "Keefektifan Virtual Class Dengan Google Classroom Dalam Pembelajaran Fisika Dimasa Pandemi Covid19," Vol. 4, No. 1, Pp. 27-33, 2020. 
[13] A. Fathurrahman, "Analisis Perubahan Sistem Pembelajaran Siswa Madrasah Aliah Negeri (Man) 1 Pesawaran Akibat Pandemi Covid-19," J. Narasi, Vol. 1, No. 1, Pp. 26-36, 2020.

[14] M. M. A. Mahardini, “Analisis Situasi Penggunaan Google Classroom Pada Pembelajaran Daring Fisika," J. Pendidik. Fis., Vol. 8, No. 2, Pp. 215-224, 2020.

[15] I. A. Brahma, "Penggunaan Zoom Sebagai Pembelajaran Berbasis Online Dalam Mata Kuliah Sosiologi Dan Antropologi Pada Mahasiswa Ppkn Di Stkip Kusumanegara Jakarta," Aksara J. Ilmu Pendidik. Nonform., Vol. 6, No. 2, Pp. 97-102, 2020.

[16] F. Suasty And A. A. Hadi, "Penggunan Media Pembelajaran Video Untuk Solusi Penurunan Pemahaman Materi Pembelajaran Ketika Belajar Online Akibat Pandemic Covid-19," Vol. 1, No. 1, Pp. 12-16, 2020.
[17] E. Nurhayati, "Meningkatkan Keaktifan Siswa Dalam Pembelajaran Daring Melalui Media Game Edukasi Quiziz Pada Masa Pencegahan Penyebaran Covid-19," J. Paedagogy J. Penelit. Dan Pengemb. Pendidik., Vol. 7, No. 3, Pp. 145-150, 2020.

[18] L. D. Herliandry, Nurhasanah, M. E. Suban, And H. Kuswanto, "Jurnal Teknologi Pendidikan Pembelajaran Pada Masa Pandemi Covid-19," J. Teknol. Pendidik., Vol. 22, No. 1, Pp. 65-70, 2020.

[19] I. M. Pustikayasa, "Grup Whatsapp Sebagai Media Pembelajaran," J. Ilm. Pendidikan, Agama Dan Kebud. Hindu, Vol. 10, No. 2, Pp. 53-62, 2019.

[20] J. W. Kusuma And Hamidah, "Platform Whatsapp Group Dan Webinar Zoom Dalam Pembelajaran Jarak Jauh Pada Masa Pandemik Covid 19," J. Ilm. Pendidik. Mat., Vol. 5, No. 1, Pp. 97-106, 2020. 